\title{
Food Production Engineering Efficiency: A Critical Analysis of the Conventional Metrics Used in Measuring Agricultural Efficiency
}

\author{
Mark McGuire \\ Bountiful Backyard, Corvallis, USA \\ Email:mark@bountifulbackyard.org
}

How to cite this paper: McGuire, M. (2017) Food Production Engineering Efficiency: A Critical Analysis of the Conventional Metrics Used in Measuring Agricultural Efficiency. Engineering, 9, 427-433. https://doi.org/10.4236/eng.2017.95025

Received: April 16, 2017

Accepted: May 24, 2017

Published: May 27, 2017

Copyright $\odot 2017$ by author and Scientific Research Publishing Inc. This work is licensed under the Creative Commons Attribution International License (CC BY 4.0).

http://creativecommons.org/licenses/by/4.0/

\begin{abstract}
An analysis is reported of conventional vs. alternative metrics used in measuring food production efficiency. Economic efficiency is driven by marketplace economics, while engineering efficiency is driven by useful energy conservation. As farming systems are optimized for maximum efficiency, how "efficiency" is defined will dictate the methods used in food production. Farming methods that are optimized in terms of economic efficiency have environmental consequences that are not inherent of engineering efficiency; however, farming methods optimized in terms of engineering efficiency have labor requirements not inherent of economic efficiency. A shift from optimizing food production in terms of economic efficiency to engineering efficiency may be necessary in order to feed a growing human population.
\end{abstract}

\section{Keywords}

Efficiency, Farming, Agriculture, Calories, Energy, Waste, Metrics, Measures

\section{Introduction}

With a growing human population, it is becoming increasingly important for potential food Calories (units of energy) to not go to waste. In optimizing food production efficiency, the definition of the metric "efficiency" must reflect a measure that is directly proportional to food availability, as opposed to marketplace economics. There is an opportunity to facilitate the optimization of production in terms of an efficiency metric that is independent of finance: engineering efficiency, $\eta_{\text {engr }}$, which is defined as useful energy output per total energy input. This is contrasted with economic efficiency, $\eta_{\text {econ }}$, defined as yield per cost. Mathematically, these definitions are [1]: 


$$
\begin{gathered}
\eta_{\text {engr }}=\frac{\text { useful energy output }}{\text { total energy input }} . \\
\eta_{\text {econ }}=\frac{\text { profit }}{\text { cost }} \sim \frac{\text { yield }}{\text { cost }} .
\end{gathered}
$$

Optimizing food production in terms of engineering efficiency as opposed to economic efficiency will mitigate challenges related to antibiotic resistance and eutrophication. The shift to the $\eta_{\text {engr }}$ model will also help ensure that useful Calories are available to future generations. In order to keep up in the marketplace, farm businesses must optimize for economic efficiency; however, to maintain resources for the public at large, it will be necessary for optimization to occur in terms of engineering efficiency.

Practical application of the $\eta_{\text {engr }}$ model necessitates the implementation of a Public framework, given the model's independence from marketplace economics. Proposed here is a legal infrastructure intended to serve in shifting farmers' food production optimization from $\eta_{\text {econ }}$ to $\eta_{\text {engr }}$, without applying new regulations to the open market.

Livestock production is the focus of this proposal; however, it is the opinion of the author that the same principles of efficiency optimization can be carried over to any crop production.

\section{Analysis}

The farm has inputs and outputs (Figure 1). For the purposes of this proposal, inputs are simplified as time, money, and energy; outputs are simplified as produce, heat, and manure. Time and money are considered the conventional costs of production (e.g. labor, overhead, feed costs), while energy is the actual caloric input (e.g. electricity, fuel, feed sustenance); produce is the commodity that the farm is producing (e.g. milk, meat, eggs, vegetables), while heat and manure are byproducts. Water may be assumed to input with energy and output with manure.

In this paper, the example used is of meat production, which for time, money, and energy outputs meat, heat, and manure. The efficiencies analyzed will be optimized in terms of money (economic efficiency) vs. Calories (engineering efficiency). While "money" and "Calories" are not listed as a farm outputs, they do serve as inputs and are therefore appropriate units to use in analyzing efficiency, representing how much useful input can be extracted from a given system's output.

\subsection{Efficiency Definitions}

The definition of "efficient" dictates the measure of a system's efficiency. Conventionally, produce is maximized while costs (time \& money) are minimized,

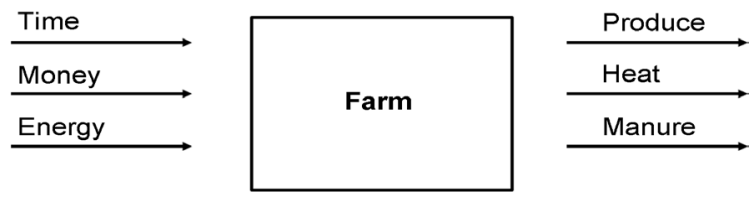

Figure 1. Generalized farm inputs (left) and outputs (right). 
because farm business optimization is based on marketplace economics. For example, one $1000 \mathrm{lb}$ steer will yield $310 \mathrm{lb}$ beef $^{*}$ valued at approx. $\$ 2.30$ per $\mathrm{lb}$ [2], returning the farmer $\$ 713.00$. This same steer will output $21,900 \mathrm{lb}$ of manure $\dagger$ [3], valued at approx. $\$ 10.84$ per ton [4] [5], returning the farmer only $\$ 108.00$ :

$1000 \mathrm{lb} /$ steer $\times 0.62$ dressing weight/live weight

$\times 0.5$ weight without fat $\&$ bones $/$ dressing weight $=310 \mathrm{lb}$ meat $/ \mathrm{steer}$.

$\rightarrow 310 \mathrm{lb}$ meat $/$ steer $\times \$ 2.30 / \mathrm{lb}$ meat $=\$ 713.00 /$ steer .

$\$ 10.84 /$ ton manure $\times 10$ tons manure $/$ steer $=\$ 108.00 /$ steer .

The difference in dollar value between meat and manure as calculated above is displayed in Figure 2 below. The farmer will maximize the production of meat, not manure, because the meat both is easier to transport and has a higher dollar value than that of manure. To optimize in terms of economic efficiency $\eta_{\text {econ }}$, meat production will be maximized while costs minimized; a cow that produces a relatively large amount of meat per feed and other costs are considered "efficient".

However, one pound of dry manure contains 8500 Btu (2150 Calories or kcal) [6] of energy, while one pound of beef contains 1200 Calories [7]. The $1000 \mathrm{lb}$ steer will output over 7,000,000 Calories in its manure, assuming its ten tons of fertilizer dehydrate down to $3290 \mathrm{lb}$ dry manure $\ddagger$. At the same time, the steer's meat yields under 400,000 Calories:

$3290 \mathrm{lb}$ manure $\times 2150$ Calories $/ \mathrm{lb}$ manure $=7060000$ Calories from manure. $(6)$

$310 \mathrm{lb}$ beef $\times 1200$ Calories $/ \mathrm{lb}$ beef $=372000$ Calories from meat.

The difference in caloric value between meat and manure as calculated above is displayed in Figure 3 below. In terms of engineering efficiency $\eta_{\text {engr }}$, meat production is negligible and the dominant factor of efficiency is the useful recycling of manure; a cow whose manure is directly recycled as a useful input elsewhere is considered "efficient".

Optimizing to maximize meat production does not necessarily correlate to energy reuse maximization. In fact, regardless of how highly economic-efficient a steer is, it will only attain a $5 \%$ engineering efficiency§:

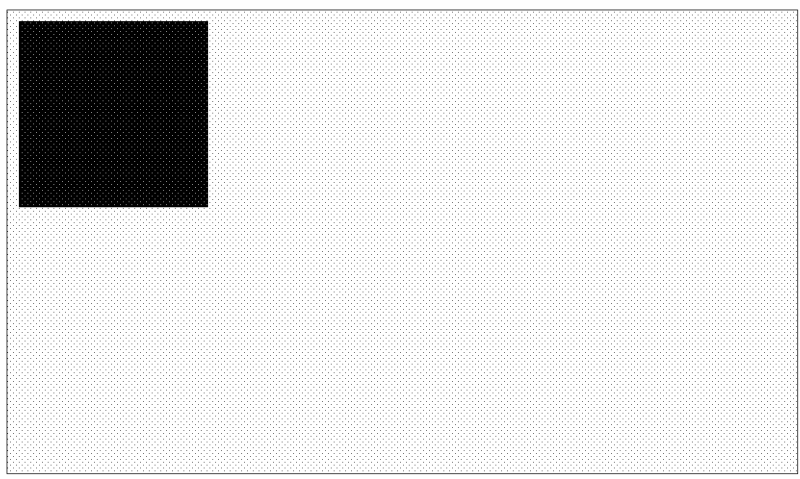

Figure 2. Relative market value per livestock head for meat

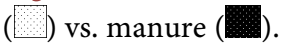




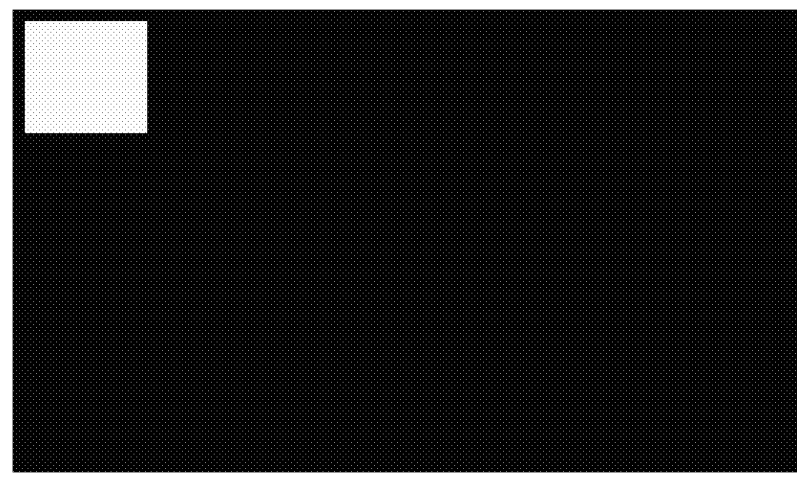

Figure 3. Relative energy value per livestock head for meat

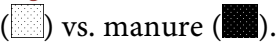

$$
\eta_{\text {engr }}=\frac{372000 \text { beef Calories }}{7060000 \text { manure Calories }}=0.0527 \cong 5 \% \text { efficiency. }
$$

On the other hand, the greater percent of manure that is usefully recycled, the higher the engineering efficiency:

$\eta_{\text {engr }}=\frac{372000 \text { beef Calories }+ \text { useful manure Calories }}{7060000 \text { manure Calories - useful manure Calories }} \cong 5$ to $100 \%$ efficiency (9)

Engineering efficiency recognizes the primary producer's primary function as soil building [8], with meat as a byproduct; economic efficiency recognizes the primary producer's primary function as meat production, with manure as a byproduct. One optimizing in terms of the Calorie; the other, the dollar.

${ }^{*}$ Assuming fat and bones are removed from a $62 \%$ dressing weight.

$\dagger$ Assuming a linear increase in weight from 0 to $1000 \mathrm{lb}$ over a two-year growth period.

\$Assuming semi-solid manure containing 85\% moisture [9].

$\S$ Assuming manure Calories equal feed Calories.

\subsection{Farming Methods}

Farming methods are determined by optimizing in terms of efficiency. The factory farm is more efficient in terms of $\eta_{\text {econ }}$, but the pasture is more efficient in terms of $\eta_{\text {engr }}$. Consider the pig: on a per-pig basis, hoop barns (pasture with shelter) require twice the labor-a major financial cost-than is required by factory farms (complete confinement) [10]. However, hoop barns are more energy efficient, demanding approximately 3.0 MJ/pig less than factory farms [11]. Additionally, manure from hoop barns [4] is valued three times higher than that from factory farms [5], based on its nutrient content:

Hoop Barn:

$$
\begin{aligned}
& (35 \mathrm{lb} \mathrm{N} / \text { ton } \mathrm{N} \times \$ 0.225 / \mathrm{lb} \mathrm{N})+\left(20 \mathrm{lb}_{2} \mathrm{O}_{5} / \text { ton } \mathrm{N} \times \$ 0.22 / \mathrm{lb}_{2} \mathrm{O}_{5}\right) \\
& +\left(23 \mathrm{lb} \mathrm{K} \mathrm{K}_{2} \mathrm{O} / \text { ton } \mathrm{K} \times \$ 0.12 / \mathrm{lb} \mathrm{K}_{2} \mathrm{O}\right)=\$ 15.035 / \text { ton }
\end{aligned}
$$

Feedlot:

$(13 \mathrm{lb} \mathrm{N} /$ ton $\mathrm{N} \times \$ 0.225 / \mathrm{lb} \mathrm{N})+\left(12 \mathrm{lb}_{2} \mathrm{O}_{5} /\right.$ ton $\left.\mathrm{N} \times \$ 0.22 / \mathrm{lb}_{2} \mathrm{O}_{5}\right)$

$+\left(9 \mathrm{lb} \mathrm{K}_{2} \mathrm{O} /\right.$ ton $\left.\mathrm{K} \times \$ 0.12 / \mathrm{lb} \mathrm{K}_{2} \mathrm{O}\right)=\$ 6.645 /$ ton . 
Higher-value manure introduces economic incentive for its transport onto cropland, avoiding challenges related to on-farm nutrient stockpiling like eutrophication and antibiotic resistance.

\subsection{Environmental Consequences}

Economic-efficient farming methods have environmental consequences. In order to ensure that manure is valued as a nutritious compost, the appropriate metric must be used in optimizing the farming process. If an inappropriate metric is used, farming methods will be optimized without regard to useful recycling of energy outputs, and the value of manure can drop until it becomes a hazard: Public health threats, such as antibiotic-resistant Staphylococcus aureī like MRSA, fecal streptococci and coliforms [12] [13], and Escherichia coli [14], have been linked with factory farm nutrient outflows. It has also been shown that carrots and lettuce will uptake tetracycline and amoxicillin (two commonly used antibiotics) [15], further devaluing manure of the factory farm, making it less likely that the waste is to be recycled for useful applications.

Antibiotic-impregnated feed can be avoided by keeping livestock in healthy pastures with shelter: a low-stress, clean environment where exercise is possible and nutritious diet available [16] [17]. This harnesses animals' own immune systems to combat infectious diseases. On pasture, manure is a valuable resource that is recycled to fertilize subsequent years' vegetation.

\subsection{Labor Considerations}

Engineering-efficient farming methods have relatively high labor requirements. This is the problem at hand: pastured livestock production, however efficient in terms of $\eta_{\text {engr }}$, is not justified under $\eta_{\text {econ }}$, given its high labor demands. As the farm becomes more automated, substitutions have been made to replace human labor. While on the surface, these technologies appear to improve efficiency, because cost (time \& money) inputs are reduced, the total energy required to achieve the same agricultural goal has been increasing with each new technology. This phenomenon is detailed in Table 1 below. It is on the smaller farms, where families work with their hands to bring forth food from the earth, where engineering efficiency is maximized.

Table 1. Comparison of energy inputs for tilling 1.0 ha of soil [18].

\begin{tabular}{|c|c|c|c|c|c|c|c|c|c|}
\hline $\begin{array}{l}\text { Tilling } \\
\text { Unit }\end{array}$ & $\begin{array}{c}\text { Required } \\
\text { Hours }\end{array}$ & $\begin{array}{l}\text { Machinery } \\
\text { Input (kcal) }\end{array}$ & $\begin{array}{l}\text { Petroleum } \\
\text { Input (kcal) }\end{array}$ & Hour/Day & $\begin{array}{l}\text { Working Human/Hour } \\
\text { Input (kcal) }\end{array}$ & $\begin{array}{c}\text { Human Daily } \\
\text { Energy Input (kcal) }\end{array}$ & $\begin{array}{l}\text { Total Human } \\
\text { Input (kcal) }\end{array}$ & $\begin{array}{l}\text { Oxen Energy } \\
\text { Input (kcal) }\end{array}$ & $\begin{array}{l}\text { Total Input } \\
\quad(\mathrm{kcal})\end{array}$ \\
\hline $\begin{array}{l}\text { Human } \\
\text { Power }\end{array}$ & 400 & 6000 & 0 & 10 & 400 & 5400 & 216,000 & 0 & 222,000 \\
\hline $\begin{array}{l}\text { Oxen } \\
\text { (pair) }\end{array}$ & 65 & 6000 & 0 & 10 & 375 & 5150 & 33,500 & 260,000 & 299,500 \\
\hline $\begin{array}{l}\text { 6-HP } \\
\text { Tractor }\end{array}$ & 25 & 47,500 & 237,600 & 10 & 200 & 3400 & 8500 & 0 & 293,600 \\
\hline $\begin{array}{l}\text { 50-HP } \\
\text { Tractor }\end{array}$ & 4 & 61,300 & 306,300 & 4 & 200 & 3400 & 1360 & 0 & 368,900 \\
\hline
\end{tabular}


This consequential trend-labor reduction in the interest of economic efficiency, at the expense of engineering efficiency-may be continuing with more-recent innovations such as solar cells, which present ecological hazards through their mining and manufacture in countries with minimal environmental regulations [19]. It also might be argued that in the optimization of $\eta_{\text {econ }}$ the human labor component has been reallocated to better uses; this may true in some cases, but not all. For example, consider the efficiency of fitness centers, where energy is outputted without accomplishing useful work.

\section{Acknowledgements}

Special thanks to Drs. Gene Pirelli and Lauren Gwin for providing the author with agricultural guidance; Dr. Christy Brekken for advice on refining the ideas written in this paper; and farmers Chris Hansen, Laura Sage, Robin Sage, and Tyler Jones for presenting their personal perspectives as food producers. Also, thanks to nonprofit directors Annette Mills and Tom Kaye for their interest in this work. Finally, thanks to family for unending support.

\section{References}

[1] Ragan, C. (2005) Explaining Different Concepts of Efficiency. Pearson Education Canada, Inc., Toronto.

[2] Kirkpatrick, D. and Neel, J. 4-H Market Steer Handbook. USDA Extension Service Program.

[3] USDA (1995) Animal Manure Management. https://www.nrcs.usda.gov/wps/portal/nrcs/detail/null/?cid=nrcs143_014211

[4] Fulhage, C. (2003) Manure Management in Hoop Structures. Nutrients and Bacterial Waste, EQ352, 1-4.

[5] Zublena, J.P., Barker, J.C., Parker, J.W. and Stanislaw, C.M. (1997) Swine Manure as a Fertilizer Source. North Carolina Cooperative Extension Service, 439.

[6] Mukhtar, S., Capareda, S. and Smith, E. (2006) Manure to Energy: Understanding Processes, Principles, and Jargon. Texas Cooperative Extension, the Texas A\&M University System, No. E-428.

[7] United States Department of Agriculture (2016) National Nutrient Database for Standard Reference.

https://ndb.nal.usda.gov/ndb/search/list?fgcd=Branded+Food+Products+Database $\& \mathrm{ds}=$ Branded + Food + Products

[8] Voisin, A. (1959) Grass Productivity. Philosophical Library, New York.

[9] United States Department of Agriculture (2005) Guidelines for Calculating Manure Dry Weight and Effectiveness. http://fargo.nserl.purdue.edu/RUSLE2_ftp/NRCS_Base_Database/Manure\%20drym atter\%20calclations/RUSLE2Manure.pdf.

[10] Duffy, M. and Honeyman, M. (2000) Labor Requirements for Market Swine Produced in Hoop Structures. Animal Science Research Reports, No. 25, Iowa State University, Ames.

[11] Lammers, P., Kenealy, M., Kliebenstein, J., Harmon, J., Helmers, M. and Honeyman, M. (2011) Energy Use in Pig Production: An Examination of Current Iowa Systems. National Center for Biotechnology Information, 90, 1056-1068.

[12] Wiggins, B. (1996) Discriminant Analysis of Antibiotic Resistance Patterns in Fecal 
Streptococci, a Method to Differentiate Human and Animal Sources of Fecal Pollution in Natural Waters. Applied and Environmental Microbiology, 62, 3997-4002.

[13] Harwood, V., Whitlock, J. and Withington, V. (2000) Classification of Antibiotic Resistance Patterns of Indicator Bacteria by Discriminant Analysis: Use in Predicting the Source of Fecal Contamination in Subtropical Waters. Applied and Environmental Microbiology, 66, 3698-3704. https://doi.org/10.1128/AEM.66.9.3698-3704.2000

[14] Krumperman, P. (1983) Multiple Antibiotic Resistance Indexing of Escherichia Coli to Identify High-Risk Sources of Fecal Contamination of Foods. Applied and Environmental Microbiology, 46, 165-170.

[15] Azanu, D., Mortey, C., Darko, G., Weisser, J., Styrishave, B. and Abaidoo, R. (2016) Uptake of Antibiotics from Irrigation Water by Plants. Chemosphere, 157, 107-114. https://doi.org/10.1016/j.chemosphere.2016.05.035

[16] Hansen, C. (2015) Interviewee, Farmer, Mosaic Farms. [Interview]

[17] Sage, R. (2015) Interviewee, Farmer, Red Bird Acres. [Interview]

[18] Pimentel, D. and Pimentel, M. (1979) Food Energy and Society. Edward Arnold, London.

[19] National Research Council (2010) Hidden Costs of Energy: Unpriced Consequences of Energy Production and Use. The National Academic Press, Washington, DC.

Submit or recommend next manuscript to SCIRP and we will provide best service for you:

Accepting pre-submission inquiries through Email, Facebook, LinkedIn, Twitter, etc. A wide selection of journals (inclusive of 9 subjects, more than 200 journals)

Providing 24-hour high-quality service

User-friendly online submission system

Fair and swift peer-review system

Efficient typesetting and proofreading procedure

Display of the result of downloads and visits, as well as the number of cited articles

Maximum dissemination of your research work

Submit your manuscript at: http://papersubmission.scirp.org/

Or contact eng@scirp.org 